\title{
Educational intervention on malignant hyperthermia with nursing professionals of the operating room
}

\author{
Intervenção educativa sobre hipertermia maligna com \\ profissionais de enfermagem do centro cirúrgico \\ Intervención educativa acerca de la hipertermia maligna con \\ profesionales de enfermería del quirófano
}

Cristina Silva Sousa ${ }^{1}$, Daniela Magalhães Bispo², Ana Lucia Mirancos da Cunha ${ }^{3}$, Ivana Lucia Correa Pimentel de Siqueira ${ }^{4}$

\footnotetext{
${ }^{1}$ Assistant Nurse, Surgical Center, Sírio-Libanês Hospital, São Paulo, SP, Brasil.

${ }^{2}$ Head Nurse, Pre-operation Unit, Sírio-Libanês Hospital, São Paulo, SP, Brasil.

${ }^{3}$ Nursing Coordinator, Surgical Center, SírioLibanês Hospital, São Paulo, SP, Brasil.

${ }^{4}$ Nursing Superintendant, Sírio-Libanês Hospital, São Paulo, SP, Brasil.
}

\section{ABSTRACT}

Objective: To evaluate the effectiveness of an educational intervention on malignant hyperthermia with operating room nurses. Method: A quasi-experimental study, aimed at an educational intervention of short duration with the nursing staff in the operating room of the institution hosting the research in the city of São Paulo, with the participation of 96 professionals. Pre-intervention tests and post-intervention tests were applied, which consisted of a lecture followed by simulation. Results: Considering the overall results of the intervention, there was a statistically significant difference $(p<0.00)$. After the educational intervention, there was an increase of the minimum and maximum scores, and average growth of 2.64 points in the knowledge of professionals when compared to the previous step. Conclusion: The educational intervention strategy favors the concept of the content developed by everyone involved and qualifies professionals to work safely.

\section{DESCRIPTORS}

Nursing Staff; Health Knowledge, Attitudes, Practice; hospital; Malignant Hyperthermia; Perioperative Nursing; Operating Room Nursing. 


\section{INTRODUCTION}

Malignant hyperthermia (MH) is an autosomal dominant pharmacogenetic disease characterized by abnormal hypermetabolic reaction to inhaled anesthetic agents from the group of halogenated and depolarizing muscle relaxants, such as succinylcholine. Typical crises have symptoms of tachycardia, tachypnea, hypercapnia, muscle rigidity, hyperthermia, metabolic acidosis and rhabdomyolysis; however, there is great clinical variability, varying from fulminant, benign and atypical forms to isolated masseter muscle spasm. Malignant hyperthermia was first described in 1960 and occurs in a frequency up to 1:10,000 of general anesthesia in children and 1:50,000 of general anesthesia in adults ${ }^{(1)}$. The first report of malignant hyperthermia in Brazil was published in 1975 during anesthesia with halothane, but there are no data on its real incidence in Brazil ${ }^{(2)}$.

The treatment consists of early recognition of triggering agents, removal of these agents and administration of Dantrolen. Malignant hyperthermia is an anesthetic emergency and there are protocols with explicit roles for each team member which should be standardized and oriented toward effective care ${ }^{(2)}$.

General anesthesia is a reversible state of unconsciousness that allows patients to undergo surgical procedures in a safe and humane way. Although it is increasingly secure, it is not entirely free of risks and complications. The morbidity associated with general anesthesia varies from minor complications that affect the patient's experience without long-term consequences to complications that can result in permanent disability ${ }^{(1)}$. However, mortality related to this procedure is rare, and the few occurrences have significantly decreased over the past five decades ${ }^{(2)}$.

Therefore, knowledge on the part of nurses in the operating room on the pathophysiology, complications and how to treat a malignant hyperthermia crisis is of real importance to be able to perform all the necessary patient care with competence and quality.

Learning has to be supported by an education system that facilities knowledge absorption by each individual, also considering the experience that the student already has on certain content as knowledge. In this sense, education has been reorganizing itself to replace the traditional model of a transforming, decentralized and integrated model in which the teacher starts to act as an agent for change, stimulating the development of the students' potential and helping them to see their limitations ${ }^{(3)}$.

Thus, the educational intervention permeated by simulation can be a strategy to develop student's capabilities. In this strategy, the student does not only receive the information from a teacher, but puts their own learning into practice, realizing their limitations when they fail in meeting care procedures in the simulation. Training professionals in simulated situations allows for exercising care, ensuring safe and capable professionals, along with ensuring patient safety.

The safety of the patient, of the hospital environment and of the anesthesia are all relevant subjects nowadays that generate a lot of discussion. Since the 1990s, this theme has been a central concern for health systems throughout the world. International research indicates that health care errors caused 44-98 thousand adverse events in 1997 in US hospitals ${ }^{(4)}$.

In 2004, the World Health Organization (WHO) launched the Worldwide Alliance for Patient Safety). One of the significant items of this action that was related to the risk to patient safety was the Safe Surgery Saves Lives. It was implemented between 2007 and 2008 in order to reduce harm to surgical patients and set safety standards to be applied in all member countries of the organization ${ }^{(5)}$.

The Association of PeriOperative Registered Nursing (AORN) has recommended evidence-based measures on a wide range of topics on security. Among them we can mention: prevention of musculoskeletal injuries, fire safety, electrical equipment, alarms, electric blankets, heating solutions, medical gas cylinder storage, anesthetic gas waste, latex, chemicals and hazardous waste ${ }^{(6)}$. Due to the increasing number of people undergoing surgeries annually, the concern of health-care institutions has turned to surgical patients ${ }^{(5)}$.

Due to the severity of the crisis, the possibility of death in misguided patients and concern for the safety of surgical patients, the creation of an educational strategy for nursing professionals of our institution was a concern. Thus, this study aims to evaluate the effectiveness of an educational intervention on malignant hyperthermia with these professionals in the operating room.

\section{METHOD}

A quasi-experimental study designed as a short duration educational intervention on $\mathrm{MH}$ with nursing technicians and nurses in the operating room of the institution - research headquarters, in the city of São Paulo. The study was approved by the Research Ethics Committee of the Institute of Education and Research of the Sírio-Libanês Hospital (Case No. 354.937/2013). All participants signed the Informed Consent (IC) form before the start of data collection, respecting the ethical principles of human research based on the Resolution 466/12 of the Conselho Nacional de Saúde ${ }^{(7)}$.

The nursing professionals who worked directly with care in the operating room at the institution studied consisted of 23 nurses and 110 nursing technicians. Based on the sample calculation with an alpha error of $0.05 \%, 96$ of the 133 professionals were inserted in our sample.

Inclusion criteria considered professionals with expertise in the operating room of the institution - research headquarters. Exclusion criteria were considered as professionals with training as a nursing assistant, as well as those who were on vacation or sick leave during the collection of research data.

Data collection was conducted in August and September 2013, using an instrument constructed by the researcher based on the practices recommended by AORN. This non-profit association represents the interests of more than 160,000 perioperative nurses by providing nursing education, standards, practices and a monthly publication on peri- 
operative nursing. The developed instrument was validated by three specialist nurses in the operating room through group discussion and submitted to Cronbach's Alpha reliability analysis. The instrument was comprised of a theoretical evaluation with ten questions, each with five possible answers, where only one alternative was correct.

This test comprised knowledge of pathology definitions, diagnosis, treatment, and side effects of medication; the existence of a protocol for crisis assistance, assistance notification procedures and the professionals that act during malignant hyperthermia crisis. Cronbach's Alpha coefficient of the questionnaire was 1.0 , indicating internal consistency of the instrument. It was administered by a nurse trained for test application and intervention procedures.

A point was awarded for each correct answer. The total score of the knowledge test corresponded to the sum of all correct answers. Knowledge on the subject was considered for scores similar or higher than $70 \%$.

The instrument was distributed to professionals who agreed to participate and signed the consent form. The questionnaire was individually answered during working hours and immediately submitted to the researcher. Although instruments contained the participant's name, the results were kept anonymous for analyses.

Due to operating room dynamics, the head nurse in charge prearranged 40 -minute training periods when some professionals could attend the training room. Professionals were selected based on their work scale, and sent to the training room only if they could be away from the operating room for the proposed period.

Questionnaires were administered in the pre-intervention phase and reapplied one week after the educational intervention.

Educational interventions on malignant hyperthermia were performed with small groups. Due to the demand of the operating room, each session was initiated immediately after the professionals became available to answer the preintervention questionnaire. Groups contained from five to 12 people, and were conducted until reaching the sample size of 96 participants.

The intervention class was taught by a lecture with explanation by the researcher. At the end of the twentyminute presentation the participants were invited to a fast simulation of care, in which each could choose the role they want to play in a malignant hyperthermia crisis (patient, anesthesiologist, nurse and technician). Thus, situation simulations were carried out within the context of an operating room in which participants showed how they should proceed for effective care. Participants watched and they gave their opinions about the scenario, reinforcing the newly acquired learning.

The PowerPoint ${ }^{\circledR}$ presentation addressed the following concepts: definition of malignant hyperthermia, pathophysiology, crisis triggering agents, occurrence of the first literature cases, crisis treatment, preparation of medication, possible side effects of medications administered, protocol concepts, demonstration of malignant hyperthermia treatment protocol created for this institution.
A week after the educational intervention, nursing technicians and nurses who participated in the intervention and answered the pre-test were invited to answer the same questionnaire in the pre-intervention phase in order to evaluate the learning, which were then submitted to the researcher.

Collected data was entered into Microsoft Excel spreadsheet in $M a c^{\circledR} 2011$, using double entry technique for analysis in the Statistical Package for Social Sciences, version 20.0 (SPSS). The analysis considered the scores of the two groups of professionals, nursing technicians and nurses, not isolated scores for each subject. The variables related to socio-demographic characteristics (age, gender and training time) and answers of the knowledge test were summarized and descriptively presented through frequency distribution, absolute values, means and standarddeviation. For statistical analysis, the Wilcoxon test was used to compare mean before and after. Significance level was set at $\mathrm{p}<0.05$.

\section{RESULTS}

There were 96 participating members (89 nursing technicians and seven nurses) of the nursing staff in the operating room, corresponding to $67.13 \%$ of the active team in the unit. The average age of professionals was $36 \pm 8.1$ years and training time $10 \pm 7.0$ years. No data was collected on length of experience in the area. The distribution of patients according to socio-demographic characteristics is shown in Table 1.

Table 1 - Socio-demographic characteristics of the participants, according to professional category - São Paulo, SP, 2013.

\begin{tabular}{lc}
\hline Variables & $\begin{array}{c}\text { Sample (n=96) } \\
\mathbf{n}(\%)\end{array}$ \\
\hline Age (years) & \\
$20-30$ & $26(27.1)$ \\
$31-40$ & $45(46.9)$ \\
$41-50$ & $20(20.8)$ \\
$51-60$ & $5(5.2)$ \\
Gender & \\
Female & $64(69.4)$ \\
Male & $32(34.7)$ \\
Graduation (years) & \\
$<5$ & $26(27.1)$ \\
$06-10$ & $35(36.5)$ \\
$11-20$ & $28(29.2)$ \\
$>20$ & $7(7.3)$ \\
\hline Total & $96(100)$ \\
\hline
\end{tabular}

Considering the overall results of the intervention, there was a significant statistical difference in knowledge after the educational intervention on malignant hyperthermia with the professionals of the surgical center $(p<0.00)$. There was an increase in the minimum and maximum score and average of 2.64 points in the knowledge of professionals when compared to the previous stage (Table 2). 
Table 2 - Evaluation Score of knowledge in the pre- and posteducational intervention tests - São Paulo, SP, 2013.

\begin{tabular}{lcccc}
\hline Variables & Minimum Maximum & Medium (SD) & p* $^{*}$ \\
\hline Before (pre-knowledge) & 1 & 5 & $5.85(1.73)$ & $0.00\urcorner$ \\
After (post-knowledge) & 9 & 10 & $8.49(1.23)$ & $0.00\urcorner$ \\
\hline
\end{tabular}

$S D$ - Standard Deviation; * Wilcoxon test; statistically significant $-p<0.05$.

In the analysis of the items included in the questionnaire, there was statistical difference in eight of the ten items of knowledge after the educational intervention $(p<0.05)$. It should be emphasized that the highest mean differences were related to the following items: treatment of malignant hyperthermia $(-0.53)$, initial clinical indicators $(-0.38)$, notification of monitoring center (-0.36) and availability of medication for treatment at the institution $(-0.35)$ (Table 3$)$.

Table 3 - Comparison of means, standard deviations and mean differences of knowledge, according to the pre- and post-assessment items of the educational intervention test - São Paulo, SP, 2013.

\begin{tabular}{|c|c|c|c|c|}
\hline \multirow[b]{2}{*}{ Variables } & \multicolumn{4}{|c|}{ Knowledge } \\
\hline & $\begin{array}{l}\text { Pre-test } \\
\text { Medium } \\
\text { (SD) }\end{array}$ & $\begin{array}{l}\text { Post-test } \\
\text { Medium } \\
\text { (SD) }\end{array}$ & Difference & $\mathbf{p}^{*}$ \\
\hline $\begin{array}{l}\text { Malignant } \\
\text { hyperthermia } \\
\text { definitions }\end{array}$ & $0.86(0.34)$ & $0.95(0.22)$ & -0.08 & $0.03-$ \\
\hline $\begin{array}{l}\text { Crises triggering } \\
\text { agents }\end{array}$ & $0.65(0.48)$ & $0.94(0.24)$ & -0.29 & $0.00-$ \\
\hline $\begin{array}{l}\text { Initial clinical } \\
\text { indicators }\end{array}$ & $0.30(0.46)$ & $0.68(0.47)$ & -0.38 & $0.00-$ \\
\hline $\begin{array}{l}\text { Malignant } \\
\text { hyperthermia } \\
\text { treatment }\end{array}$ & $0.47(0.50)$ & $1.00(0.00)$ & -0.53 & $0.00-$ \\
\hline Main side effects & $0.58(0.50)$ & $0.70(0.46)$ & -0.11 & 0.07 \\
\hline $\begin{array}{l}\text { Medication } \\
\text { availability at the } \\
\text { hospital }\end{array}$ & $0.65(0.48)$ & $1.00(0.00)$ & -0.35 & $0.00-$ \\
\hline $\begin{array}{l}\text { Availability of care } \\
\text { protocol for crisis }\end{array}$ & $0.27(0.45)$ & $0.56(0.50)$ & -0.29 & $0.00-$ \\
\hline $\begin{array}{l}\text { Incidence of } \\
\text { prevention for } \\
\text { patients with a } \\
\text { previous diagnosis } \\
\text { and high risk }\end{array}$ & $0.67(0.47)$ & $0.76(0.43)$ & -0.09 & 0.12 \\
\hline $\begin{array}{l}\text { Notification of } \\
\text { monitoring centers }\end{array}$ & $0.60(0.49)$ & $0.97(0.17)$ & -0.36 & $0.00-$ \\
\hline $\begin{array}{l}\text { Professionals } \\
\text { involved in the } \\
\text { treatment of attacks }\end{array}$ & $0.80(0.40)$ & $0.94(0.24)$ & -0.14 & $0.05-$ \\
\hline
\end{tabular}

\section{DISCUSSION}

The educational intervention based on lectures and basic simulation of care makes it possible to increase operating room nursing professionals' knowledge about malignant hyperthermia. A favorable factor was the availability on the part of the nursing team to compose the study groups. The availability of the apprentice is considered an internal factor that is inherent in every person, where the individual leaves the condition of being passive and becomes active. If the individual has no availability and even if the material is potentially significant, the subject may choose to simply memorize $i t^{(8)}$.

The use of treatment simulations is a teaching method designed to facilitate a safe environment for learning exercises, by providing a path between formal education and professional practice, especially effective for rare but potentially fatal situations, such as malignant hyperthermia ${ }^{(9)}$.

Professional training also allows the creation of a coordinated multidisciplinary team, such as a Rapid Response Team $(\mathrm{RRT})^{(10)}$, allowing the best chance of success for patient recovery in a crisis. The creation of Rapid Response Teams in health institutions has increased in parallel with the increased interest in improving the quality of care ${ }^{(11)}$.

Two pieces of data have become relevant to the present study: gender and training time of the participants. The sample was characterized by a population of women with experience in the area. Nursing has historically been characterized as a typically female profession, even though the population of male nurses has tripled in the last decade ${ }^{(12)}$. The training time was 6-10 years - 36.5\% (35) - followed by $11-20$ years $-29.2 \%(28)$ - denoting professionals with experience.

The effectiveness of the educational intervention was evidenced by an increased average of correct answers in the post-intervention knowledge test (pre-test resulted in 5.85 , and post-test resulted in 8.49 points) with a statistically significant difference. Similar results were found in some studies that evaluated the effectiveness of educational programs ${ }^{(9,13-14)}$. In general, malignant hyperthermia is little addressed in professional training courses. The results of previous knowledge obtained in this study were found to be unsatisfactory with less than $70 \%$ answers correct, probably due to the lack of information received by these professionals during their training.

An American study with undergraduate nursing students has evidenced the lack of information on treatment and management of malignant hyperthermia, resulting in the creation of an educational strategy for this group ${ }^{(9)}$.

In Brazil, there are no studies focusing on educational strategies with this theme. However, AORN recommends that all professionals within the operating room that can aid in response to a malignant hyperthermia crisis should receive skill training and perform validation activities applicable to their duties on the actions necessary to effectively manage this type of event ${ }^{(15)}$. The American Association of Nurse Anesthetists (AANA) also recommends that certified anesthetic nurses maintain competence through continuing education in the treatment of malignant hyperthermia ${ }^{(16)}$.

Some items of lesser knowledge can be highlighted in the pre-test phase: pathology, diagnosis and treatment. This result can probably be explained by the educational focus of the professional, since in general, doctors deepen their knowledge in diagnosis and treatment, and nurses in care.

One of the items that caught our attention was the lack of staff knowledge regarding notification of the monitoring center. Due to the poor knowledge of nursing professionals, lack of notification of a patient with malignant hyperthermia leads to under-reporting of existing cases. 
The SS-20 Resolution, established by the State of São Paulo on February 22,2006, regulates malignant hyperthermia as a disease subject to immediate notification. It is the health care professional's duty to fill out the Compulsory Notification Form of Adverse Events and forward it to the Pharmacovigilant of their state ${ }^{(17)}$.

Regarding the availability of medication for treatment and the existence of treatment protocols, the participants had some knowledge, but no control over the origin or custody of medicine and patient care. Both are related to the knowledge of their work unit and the appropriate care, to ensure patient safety.

The nursing staff should be aware that there is a direct correlation between the severity of an episode of malignant hyperthermia and the opportunity for treatment. Therefore, any delay in the early recognition and prompt treatment of a patient with malignant hyperthermia can result in sudden death by cardiac arrest, brain injury, multiple organ failure or disseminated intravascular coagulation $(\mathrm{DIC})^{(15,18-19)}$.

Since 2000, operating room actions have focused on patient safety. Therefore, protocols and security procedures were put in practice in the operating room and nurses skills have widened ${ }^{(20)}$. In 2007, with better trained teams, early diagnosis and prompt treatment, the mortality rate was around 5\%; a clear difference when compared to the $80 \%$ in the 1970 's ${ }^{(10)}$.

Even with the decrease in mortality rates presented in recent years, the scope of operating room nurses still presents many challenges. Therefore, it is still extremely important that the recommendation of recurrent training is offered for professional development, and service protocols are created for this event ${ }^{(21)}$.

\section{CONCLUSION}

Despite there only being few results of studies related to nursing on malignant hyperthermia, particularly with regard to the knowledge of staff on the subject which makes it harder to discuss literature findings, the results show effectiveness of the educational intervention performed with an increase in knowledge gained by the team.

The educational intervention strategy is efficient and favors the concept of content developed by all involved in this process, qualifying professionals to work safer and quicker in patient care in events related to the disease.

It is the nurse's responsibility as a team leader to be continuously up-to-date with scientific knowledge, and to disseminate this knowledge among their staff in order to upgrade the skills of the professionals, so that in this way the patients can be assisted with excellence.

\section{RESUMO}

Objetivo: Avaliar a efetividade de uma intervenção educativa sobre a hipertermia maligna com profissionais de enfermagem do centro cirúrgico. Método: Estudo quase-experimental, voltado a uma intervenção educativa de curta duração com a equipe de enfermagem do centro cirúrgico da instituição-sede da pesquisa, situada na cidade de São Paulo, com a participação de 96 profissionais. Foram aplicados pré e pós-teste à intervenção, que consistiu em aula expositiva seguida de simulação. Resultados: Considerando-se os resultados globais da intervenção, houve diferença estatística significativa $(\mathrm{p}<0,00)$. Após a intervenção educativa, observou-se um incremento das pontuações mínima e máxima, bem como média de crescimento de 2,64 pontos no conhecimento dos profissionais quando comparado à etapa anterior. Conclusão: A estratégia de intervenção educativa favorece a abstração do conteúdo desenvolvido por todos os envolvidos e qualifica os profissionais para atuar com segurança.

\section{DESCRITORES}

Equipe de enfermagem; Conhecimentos, Atitudes e Prática em Saúde; Hipertermia Maligna; Enfermagem Perioperatória; Enfermagem de Centro Cirúrgico.

\section{RESUMEN}

Objetivo: Evaluar la efectividad de una intervención educativa acerca de la hipertermia maligna con profesionales de enfermería del quirófano. Método: Estudio casi experimental, volcado a una intervención educativa de corta duración con el equipo de enfermería del quirófano de la institución sede de la investigación, ubicada en la ciudad de São Paulo, con la participación de 96 profesionales. Se aplicaron pre y post prueba a la intervención, que consistió en clase expositiva seguida de simulación. Resultados: Considerándose los resultados globales de la intervención, hubo diferencia estadística significativa $(p<0,00)$. Después de la intervención educativa, se observó un incremento de los puntajes mínimo y máximo, así como promedio de crecimiento de 2,64 puntos en el conocimiento de los profesionales cuando comparado a la etapa anterior. Conclusión: La estrategia de intervención educativa favorece la abstracción del contenido desarrollado por todos los involucrados y cualifica a los profesionales para actuar con seguridad.

\section{DESCRIPTORES}

Grupo de Enfermería; Conocimientos, Actitudes y Práctica en Salud; Hipertermia Maligna; Enfermería Perioperatoria; Enfermería de Quirófano.

\section{REFERENCES}

1. Harris M, Chung F. Complications of general anesthesia. Clinic Plastic Surg. 2013;40(4):503-13.

2. Silva HCA, Almeida CS, Brandao JCM, Silva CAN, Lorenzo MEP, Ferreira CBN, et al. Malignant hyperthermia in Brazil: analysis of hotline activity in 2009. Rev Bras Anestesiol. 2013;63(1):13-9.

3. Dias CL, Alves AM, Ynoue AT, Silva CS. O modo de entender e fazer a Educação: o professor frente à formação critico-reflexiva na educação superior. Colloquium Human. 2010;7(1):50-7. 
4. Khon L, Corrigan J, Donaldson M. To err is human: building a safer health system [Internet]. Washington: The National Academies Press; 2000 [cited 2014 June 10]. Available from: http://www.nap.edu/catalog.php?record_id=9728

5. Brasil. Ministério da Saúde; Agência Nacional de Vigilância Sanitária; Organização Pan-Americana da Saúde. Aliança Mundial para a Segurança do Paciente. Cirurgias seguras salvam vidas: segundo desafio global para a segurança do paciente [Internet]. Brasília; 2009 [citado 2014 jun. 10]. Disponível em: http://www.into.saude.gov.br/upload/arquivos/pacientes/cirurgias_seguras/Seguran\%C3\%A7a_do_ Paciente_guia.pdf

6. Hughes AB. Implementing AORN recommended practices for a safe environment of care. AORN J. 2013;98(2):153-66.

7. Brasil. Ministério da Saúde; Conselho Nacional de Saúde. Resolução 466, de 12 de dezembro de 2012. Dispõe sobre as diretrizes e normas regulamentadoras de pesquisas envolvendo seres humanos [Internet]. Brasília; 2012 [citado 2014 jun.15]. Disponível em: http:// conselho.saude.gov.br/resolucoes/2012/Reso466.pdf

8. De Mattia AL, Barbosa MH, Rocha ADM, Farias HL, Santos CA, Santos DM. Hypothermia in patients during the perioperative period. Rev Esc Enferm USP. 2012;46(1):60-6.

9. Cain CL, Riess ML, Gettrust L, Novalija J. Malignant hyperthermia crisis: optimizing patient outcomes through simulation and interdisciplinary collaboration. AORN J. 2014;99(2):301-8; quiz 309-11.

10. Hirshey Dirksen SJ, Van Wicklin SA, Mashman DL, Neiderer P, Merritt DR. Developing effective drills in preparation for a malignant hyperthermia crisis. AORN J. 2013;97(3):329-53.

11. Veiga VC, Carvalho JC, Amaya LEC, Gentile JKA, Rojas SSO. Atuação do Time de Resposta Rápida no processo executivo de atendimento da parada cardiorespiratória. Rev Soc Bras Clín Méd. 2013;11(3):258-62.

12. Mendoza IYQ, Peniche ACG, Araujo Püschel VA. Knowledge of hypothermia in nursing professionals of surgical center. Rev Esc Enferm USP. 2012;46(n.spe):123-9.

13. Mendoza IYQ, Peniche ADG. Educational intervention regarding hypothermia: a teaching strategy for education in the Surgery Department. Rev Esc Enferm USP. 2012;46(4):849-55.

14. He HG, Jahja R, Lee TL, Ang EN, Sinnappan R, Vehviläinen-Julkunen K, et al. Nurses' use of nonpharmacological methods in children's postoperative pain management: educational intervention study. J Adv Nurs. 2010;66(11):2398-409.

15. Association of PeriOperative Registered Nurses. Malignant Hyperthermia Guideline. Perioperative Standards and Recommended Practices. Denver: AORN; 2012. p. 621-41.

16. American Association of Nurse Anesthetists. Position statement number 2.5: malignant hyperthermia crisis preparedness and treatment [Internet]. Park Ridge: ANA; 2010 [cited 2014 June 10]. Available from: http://www.aana.com/resources2/professionalpractice/Documents/ PPM\%20PS\%202.5\%20MH\%20Preparedness\%20and\%20Treatment.pdf

17. São Paulo (Estado). Secretaria de Estado da Saúde. Resolução SS n. 60, de 22 de fevereiro de 2006. Atualiza a lista de doenças de notificação compulsória no estado de São Paulo [Internet]. São Paulo; 2006 [citado 2014 jun. 10]. Disponível em: ftp://ftp.cve.saude.sp.gov. br/doc_tec/nive/dncsp_220206.pdf

18. Escobar DJ. Malignant hyperthermia. Rev Med Clin Condes. 2011;22(3):310-5.

19. Poore SO, Sillah NM, Mahajan AY, Gutowski KA. Patient safety in the operating room: II. Intraoperative and postoperative. Plast Reconstr Surg. 2012;130(5):1048-58.

20. Sousa CS, Diniz TRZ, Cunha ALSM. Malignant hyperthermia: proposing a care protocol for surgical centers. J NursUFPE On Line [Internet]. 2013 [cited 2014 June 10];7(11):6714-8. Available from: http://www.revista.ufpe.br/revistaenfermagem/index.php/revista/article/ view/4878/pdf_4061

21. Sousa CS, Gonçalves MC, Lima AM, Turrini RNT. Advances in the role of surgical center nurses. J NursUFPE On Line [Internet]. 2013 [cited 2014 June 10]];7(n.spe):915-23. Available from: http://www.revista.ufpe.br/revistaenfermagem/index.php/revista/article/view/4888/ pdf_3820 